\title{
NUMBER OF BLACK-PIGMENTED ANAEROBIC BACTERIA CONTAINED IN THE GINGIVAL CREVICULAR FLUID (GCF) OF PATIENTS SUFFERING FROM THE CHRONIC PERIODONTITIS AND AGGRESSIVE PERIODONTITIS
}

\author{
Depi Praharani*, Peni Pujiastuti*, Melok Aris Wahyukundari*, Yuliana Mahdiyah Daat Arina*, Desi Sandra
} Sari*

${ }^{*}$ Departement of Periodontics, Faculty of Dentistry, University of Jember, Indonesia

Correspondence: praharanidepi.fkg@unej.ac.id

\section{Keywords:}

Periodontal disease, Gingival Crevicular Fluid (GCF), anaerobic bacteria, pocket

\section{ABSTRACT}

Background: Chronic Periodontitis (CP) and Aggressive Periodontitis (AP) are chronic inflammation diseases in the dental supporting tissues characterized by the existence of pocket inside, alveolar bone attachments and damages rapidly leading to the dental loss. The pocket inside is related to the existence of the dominating bacteria known as the black-pigmented anaerobic bacteria group. This black-pigmented bacteria group consists of Porphyromonas spp and Prevotella spp genus abundantly found in the periodontal pocket. This research aims at examining the number of blackpigmented bacteria taken from the Gingival Crevicular Fluid (GCF) of patients suffering from the Chronic Periodontitis (CP) and Aggressive Periodontitis (AP). Method: The ethical clearance was obtained from the Faculty of Dentistry, Universitas Jember. The subjects diagnosed with the Chronic Periodontitis $(C P)$ and Aggressive Periodontitis were recorded into pocket and then the panoramic Rontgen photographs were taken. The Gingival Crevicular Fluid (GCF) of patients were taken using a sterile paper point and then inserted to the pocket inside for 30 seconds. The paper point was then inserted to the PBS and examined using a microbiological test on blood agar media. The mouth cavity hygiene levels of subjects were recorded using OHI-S, while the needs on periodontal treatments using CPITN. The statistical test was conducted using $T$-test with the value of $p<0.05$.

Result: he result shows that subjects suffering from the Chronic Periodontitis $(C P)$ and Aggressive Periodontitis (AP) had the pocket depth differences yet not significant $(p>0.05)$. this shows the same periodontal disease severity of both Chronic Periodontitis (CP) and Aggressive Periodontitis (AP). The bacteria culture result shows that the number of black- pigmented anaerobic bacteria in both Chronic Periodontitis (CP) and Aggressive Periodontitis (AP) was not significant $(p>0.05)$. The mouth hygiene level of patients suffering from the Chronic Periodontitis (CP) and Aggressive Periodontitis (AP) was at the medium (93\%) level with the needs on periodontal treatments of scaling and root planning (85\%)

Conclusion: The number of black-pigmented anaerobic bacteria colonies belonging to the patients suffering from the Chronic Periodontitis (CP) and Aggressive Periodontitis (AP) was same.

\section{INTRODUCTION}

Periodontitis is defined as infectious disease in the dental supporting tissues caused by specific microorganisms called periodonto pathogenic bacteria causing inflammation and progressive damages1,2. Chronic periodontitisis a disease 
which is commonly experienced by most age groups, yet is more frequently experienced byadults and old people throughout the world. The prevalence and severity increase along with the increasing age. Meanwhile, aggressive Periodontitis is characterized by the severe periodontal attachment loss rapidly and more frequently experienced by teenagers and young adults3-5.

Most periodontal pathogenic bacteria are Gramnegative and anaerobic bacteria synergized each other. Among the most important species the blackpigmented anaerobic bacteria group, such as Bacteroidaceae, Prevotella and Porphyromonas species. Black-pigmented anaerobic bacteria are the pathogenic bacteria group in the mouth cavity and related to the gingivitis, periodontitis, endodontic infection, and odontogenic abscess. Besides, this species has the colony characteristics with brown or black color in blood agar media 6-8. Research has proven that there is a relationship between pocket depth and number of Blackpigmented anaerobic bacteria colony in patients suffering from the Aggressive Periodontitis (AP), where the deeper the pocket, the more the number of bacteria will be. The probability of Porphyromonas gingivalis bacteria is found more in the pocket depth of $<6 \mathrm{~mm}$. Prevotella intermedia is significantly found more in the pocket depth of 4-6 $\mathrm{mm}$. Meanwhile, both species are not found in the pocket depth of $2 \mathrm{~mm} \mathrm{9-11}$

The purpose of this research was to examine the number of black-pigmented anaerobic bacteria in the Gingival Crevicular Fluid (GCF) of patients suffering from Chronic Periodontitis (CP) and Aggressive Periodontitis (AP) and figure out the status of mouth hygiene and periodontal treatment needs.

\section{METHODS}

This experimental research type has been previously permitted by the commission of health research ethics of the dentistry faculty of Universitas Jember No.1030/UN.25.8/KEPK/DL/2020. The subjects were diagnosed with Chronic Periodontitis (CP) and Aggressive Periodontitis (AP) by the periodontist visiting the Teeth and Mouth Dentistry Hospital (known as RSGM) of Faculty of Dentistry, Universitas Jember with the age range of 20-35 years old, not suffering from systemic abnormality, not having the smoking habit, not using a mouth wash or antibiotic minimally in the last 6 months, not having periodontal treatment minimally in the last 6 months, and not pregnant or menstruation and signing the informed consent as the agreement to become the research subjects. The status examination of mouth hygiene and periodontal treatment needs.

The data collection related to the status of mouth hygiene used Oral Hygiene Index Simplified (OHI- S) from Green and Vermillion. OHI-S is measuring scale on the levels of teeth and mouth hygiene consisting of calculus index simplified $(\mathrm{Cl}-$ S) and debris index simplified (DI-S). The selected teeth as the index teeth are tooth $16,11,26,36,31$ and 46. The OHI-S result is the summation of both $\mathrm{DI}-\mathrm{S}$ and $\mathrm{Cl}-\mathrm{S}$ scores. The data collection related to periodontal treatment needs used the Community Periodontal of Treatment Needs (CPITN). The selected teeth as the index teeth are tooth 17,16 , $11,26,27,37,36,31,46$ and 47.12

\section{Sample-Taking Procedures}

The pockets were examined in all teeth of patients suffering from Chronic Periodontitis (CP) and Aggressive Periodontitis (AP) using the probe UNC 15, and then the panoramic radiography 
photograph was taken to see the biggest alveolar bone damages. Each Gingival Crevicular Fluid (GCF) of patients suffering from Chronic Periodontitis (CP) and Aggressive Periodontitis (AP) was taken from the tooth elements and the deepest pockets. The teeth were previously cleaned with the sterile cotton rolls to eliminate the supra-gingival plaque. The sterile paper point was inserted to the pocket and left for 30 seconds. The paper point was moved, placed on the eppendorf tube of $1.5 \mathrm{ml}$ containing the phosphate buffer saline (PBS) as much as $1 \mathrm{ml}$ PBS and taken to the microbiology laboratory for the microbiological test 9,12 .

\section{Microbiological Test}

The PBS fluid containing paper point was shaken with fortex mixer for 10 seconds. $0.5 \mathrm{ml}$ of the fluid was planted in blood agar media. The blood agar media composition consists of $2 \mathrm{ml}$ brucella broth added with $0.4 \mu \mathrm{l} / \mathrm{ml}$ vitamin $\mathrm{K} 1$ and $5 \mu \mathrm{l} / \mathrm{ml}$ hemin and then given with $10 \%$ sheep blood. Media and bacteria were inserted into the anaerobic jar and incubated in the air containing 10\% CO2 using GasPack $\mathrm{CO} 2$ generating sachet with the temperature of $370 \mathrm{C}$ for 7-14 days. The number of black-pigmented anaerobic bacteria colonies was calculated using colony counter 9 .

\section{Data Analysis}

The obtained data from the research result was examined using T-test with the significant level of $5 \%(p<0.05)$.

\section{RESULTS}

The Gingival Crevicular Fluid (GCF) was taken from ten research subjects consisted of 5 subject suffering from the Chronic Periodontitis (CP) and 5 subjects suffering from the Aggressive Periodontitis (AP), and then examination on the levels of mouth hygiene was measured using $\mathrm{OHI}-$ $S$ and periodontal treatment needs were measured using CPITN. The examination result can be seen in Table 1 and Table 2.

Table 1 shows that the levels of mouth hygiene belonging to the research subjects (93\%) were categorized into medium, $7 \%$ of research subjects had the level of mouth hygiene categorized into poor, and no research subject has the level of mouth hygiene categorized into good.

In addition, Table 2 shows that $85 \%$ of research subjects did not have pockets, while respectively $35 \%$ of those subjects experienced gingival bleeding, $10 \%$ had the pocket of $4-5 \mathrm{~mm}$, and no subject had the pocket depth of $6 \mathrm{~mm}$ or more.

The data related to the examination result on the pocket depth can be seen in Table 3. The result shows that the pocket belonging to the patients suffering from the Aggressive Periodontitis (AP) was deeper $(7 \mathrm{~mm})$ then that belonging to those suffering from the Chronic Periodontitis. The panoramic radiography examination shows the existence of alveolar bone resorption reaching the root half-length in the patients suffering from the Aggressive Periodontitis (AP) while those suffering from the Chronic Periodontitis (CP), the alveolar bone resorption was not more than one third of the root length, yet statistically there was no difference in the pocket depth between the patients suffering from the Chronic Periodontitis (CP) and those suffering from the Aggressive Periodontitis (AP). The result of colony calculation shows that the black-pigmented anaerobic bacteria colonies in the patients suffering from the Chronic Periodontitis (CP) had no significant difference with that in the periodontal pocket of patients suffering from the Chronic Periodontitis (CP) and Aggressive Periodontitis (AP). 
Table 1. OHI-S Examination Result

\begin{tabular}{lcc}
\hline \multicolumn{1}{c}{ OHI-S } & Number of Research Subjects & $\%$ \\
\hline Good $(0.0-1.2)$ & 0 & 0 \\
Medium (1.3-3.0) & 8 & 93 \\
Poor (3.1-6.0) & 2 & 7 \\
\hline
\end{tabular}

Table 2. CPITN Examination Result

\begin{tabular}{|c|c|c|c|}
\hline Code \& Criteria & $\begin{array}{l}\text { Number of } \\
\text { Research } \\
\text { Subjects }\end{array}$ & $\%$ & Classification of Treatment Needs \\
\hline 0 : healthy periodonsium & 0 & 0 & TN-0: No Treatment \\
\hline 1: gingival bleeding & 1 & 5 & TN-1: personal increasing oral hygiene \\
\hline $\begin{array}{l}\text { 2: all probe black markers are } \\
\text { seen, yet calculus or other plaque } \\
\text { retention factors are seen or felt } \\
\text { during probing }\end{array}$ & 7 & 85 & $\begin{array}{l}\text { TN-2: scaling and eliminating plaque retention } \\
\text { factors and oral hygiene instructions }\end{array}$ \\
\hline $\begin{array}{l}\text { 3: Pathological pocket with the } \\
\text { depth of } 4-5 \mathrm{~mm} \text { in which only a } \\
\text { part of probe black markers is } \\
\text { seen }\end{array}$ & 2 & 10 & $\begin{array}{l}\text { TN-2: scaling and eliminating the plaque retention } \\
\text { factors and oral hygiene instructions }\end{array}$ \\
\hline $\begin{array}{l}\text { 4: Pathological pocket with the } \\
\text { depth of } 6 \mathrm{~mm} \text { or more that the }\end{array}$ & & & TN-3: Complex Treatment \\
\hline probe black markers are seen & 0 & 0 & \\
\hline $\begin{array}{l}X: \text { there is only one or no tooth in } \\
\text { one sextant (molar } 3 \text { is not taken } \\
\text { into account unless molar } 3\end{array}$ & & & TN-0: No Treatment \\
\hline $\begin{array}{l}\text { functions as } \\
\text { molar 2) }\end{array}$ & 0 & 0 & \\
\hline
\end{tabular}

Table 3. Distribution of pocket depth and Number of black-pigmented anaerobic Bacteria Colonies

\begin{tabular}{cccc}
\hline No. Diagnosis & Tooth & Pocket Depth $(\mathbf{m m})$ & $\begin{array}{c}\text { Number of black- } \\
\text { pigmented anaerobic } \\
\text { bacteria (cfu/ml) }\end{array}$ \\
\hline 1. & 44 & 4 & $0.8 \times 10^{2^{* *}}$ \\
\hline 2. & 42 & 4.5 & $1.1 \times 10^{2^{* *}}$ \\
\hline 3. & 32 & 4.5 & $0.8 \times 10^{2^{* *}}$ \\
\cline { 2 - 4 } & & &
\end{tabular}




\begin{tabular}{|c|c|c|c|c|}
\hline 4 & Chronic Periodontitis & 31 & 5 & $1.7 \times 10^{2 * *}$ \\
\hline 5 & (CP) & 33 & 5 & $2.2 \times 10^{2^{* *}}$ \\
\hline 1. & & 26 & 7 & $2.9 \times 10^{2 \star \star}$ \\
\hline 2. & & 27 & 5 & $1.1 \times 10^{2 * \star}$ \\
\hline 3. & Aggressive Periodontitis & 21 & 5 & $1.5 \times 10^{2 * \star}$ \\
\hline 4. & $(\mathrm{AP})$ & 11 & 4 & $0.7 \times 10^{2^{*}}$ \\
\hline 5 & & 16 & 5 & $1.9 \times 10^{2 * *}$ \\
\hline
\end{tabular}

Description: **not significant $(p>0.05)$

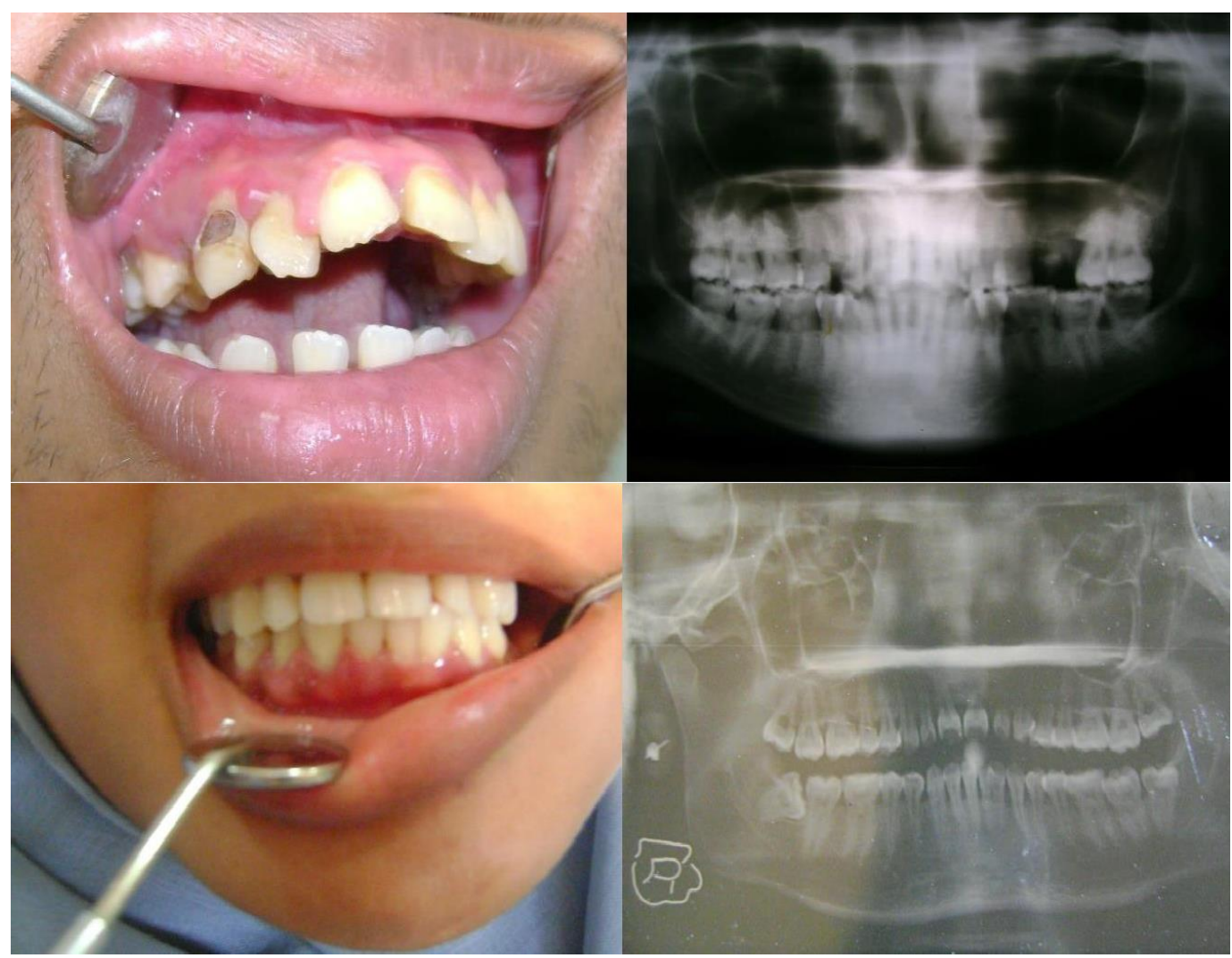

Figure 1. (A). The labial depiction of chronic periodontitis experienced by a 35-year-old man without systemic diseases or risk factors and the existence of local factors. The panoramic radiography shows that there was alveolar bone-resorption. (B) The labial depiction of chronic periodontitis experienced by a 32-year-old woman without systemic diseases or risk factors shows that there were only few local factors without the existence of diastema. The panoramic radiography shows that there was alveolar bone-resorption at almost all teeth.

\section{DISCUSSION}

Plaque accumulation as the main agent initiates the periodontal disease etiology. The attachment and bone loss is related to the development of gramnegative organisms in the sub-gingival plaque biofilm. 13,14 In the periodontitis disease, the tissue colonization is initiated by the pathogenic bacterial species. The bacteria then pathogenically invade the bacterial products inserting to the periodontal 
tissues that the bacteria or their substances interact with the host cells both directly or indirectly causing the periodontal tissue degradation and resulting in tissue damages 15.

The research shows that the aggressive periodontitis had the alveolar bone resorption three or four times higher than the chronic periodontitis. This shows that the level of attachment loss in the aggressive periodontitis is much higher than that in the chronic periodontitis16.

The black-pigmented anaerobic bacteria in the patients suffering from periodontitis were not found in the healthy area and generally found in areas experiencing inflammation. Most samples with positive $\mathrm{P}$. gingivalis were also with positive $\mathrm{P}$. intermedia 17-20

Periodonto pathogen mostly discussed in the recent years: Aggregatibacter actinomycetemcomitans, Tannerella forsythia, Treponema denticola, P. gingivalis, P. intermedia, Campylobacter rectus and spirochetes. There are is substantive evidence proving that these bacteria are related to and responsible for the existence of alveolar bone resorption and attachment loss, especially in the aggressive periodontitis. 15

The previous research shows that the highest $P$. intermedia and A. actinomycetemcomitans were in patients with the pocket depth (PD) of $>3 \mathrm{~mm}$ and attachment loss of $3.1-5 \mathrm{~mm}$ revealing that $P$. intermedia and P. gingivalis were found in $31.8 \%$ of samples with the pocket depth (PD) of $3-5 \mathrm{~mm}$, $40.9 \%$ of samples with the pocket depth (PD) of 5 $7 \mathrm{~mm}$ and $50 \%$ of samples with the pocket depth (PD) of $>7 \mathrm{~mm} .7,12$ The number differences of bacteria was shown in the deep and shallow periodontal pocket due to the presence of oxygen pressure (pO2) and redox potential (Eh). The oxygen pressure in the deep pocket was very low since the deep pocket has only a little oxygen. The deep pocket with oxygen pressure lower than that in the shallow pocket was caused by a large amount of purulent debris plaque contained in the pocket when compared to that in the shallow pocket. In addition, the deposit mass can inhibit the oxygen diffusion because the deep pocket contains low oxygen pressure. Besides, the metabolism of bacteria can chemically decrease the oxygen molecules and result in the decreasing oxygen pressure 8,1 .

The status of mouth hygiene measured with the number of plaque and supra-gingival calculus had a significant impact on periodontal health. In this research, most subjects had the level of mouth hygiene categorized into medium (96\%), while the scaling treatment needs was with CPITN score of 2 and root planning of $85 \%$. These results were reflected from the mouth hygiene knowledge level categorized into poor; not brushing the teeth twice a day, and rarely visiting the dentist.21,22

\section{CONCLUSION}

The Gingival Crevicular Fluid (GCF) of patients suffering from the Chronic Periodontitis (CP) and Aggressive Periodontitis (AP) contained blackpigmented anaerobic bacteria which number was same with that in the periodontal pocket.

\section{ACKNOWLEDGEMENT}

This research was funded with the grant obtained by the researchers in the research group (known as KeRis/Kelompok Riset) Riset (KeRis) of Universitas Jember, No. 11872/UN25/LT/2020.

\section{REFERENCES}

1. Hienz, Stefan A; Paliwal, Sweta, Ivanovski

2. S. Mechanisms of bone resorption in periodontitis. J Immunol Res 2015; 2015: $1-10$.

3. Carranza NT. Newman and Carranza Clinical Periodontology. 13th Ed. China: Elsevier, 2018. 
4. Armitage GC. Development of a Classification System Classification System For Periodontal Diseases and Conditions. Annal Periodontology 1999; 4: 1-6.

5. Benoist HM, Seck-Diallo A, Diouf $A$, et al. Profile of chronic and aggressive periodontitis among Senegalese. J Periodontal Implant Sci 2011; 41: 279-84.

6. Susin C, Haas AN, Albandar JM.

7. Epidemiology and demographics of aggressive periodontitis. Periodontol 2000 2014; 65: 27-45.

8. Chahboun $\mathrm{H}$, Arnau MM, Herrera D, et al. Bacterial profile of aggressive periodontitis in Morocco: a cross-sectional study. BMC Oral Health 2015; 15: 1-8.

9. Siqueira JF, Rôüas IN, Oliveira JCM, et al. Molecular detection of black-pigmented bacteria in infections of endodontic origin. $J$ Endod 2001; 27: 563-566.

10. Bavana Sri S, Sarah Sathiyawathie R, Gurunathan D. Pigment-producing bacteria in periodontal disease. Drug Invent Today 2019; 12: 624-625.

11. Sari DS. Hubungan Kedalaman Poket Dengan Jumlah Bakteri Blackpigmented Anaerob Pada Penderita Aggressive Periodontitis [The Relationship of Pocket Depth with Number of blackpigmented Anaerobic Bacteria in Patients suffering from Aggressive Periodontitis]. Stomatonagti J 2010; 3: 1-12.

12. Joshipura V, Yadalam U, Brahmavar B. Aggressive periodontitis: A review. J Int Clin Dent Res Organ 2015; 7: 11-17.

13. Albandar JM. Aggressive and acute periodontal diseases. Periodontology 2000 2014; 65: 7-12.

14. Hamdoon S, Abdul-Rahman G. Prevalence of Anaerobic Bacteria in Periodontitis in Relation to Pocket Depth. Al-Rafidain Dent J 2014; 14: 320-328.
15. Carranza NT. Clinical Periodontology9th.WB Saunder Company 2012

16. Dumitrescu AL. Etiology and pathogenesis of periodontal disease. London: Springer Heidelberg, 2010.

17. Bruce V. Hofkin. Living in A Microbial World. New York: Garland Science, Taylor and Francis Group, 2011.

18. Popova C, Dosseva-Panova V, Panov V. Microbiology of periodontal diseases. A review. Biotechnol Biotechnol Equip 2013; 27: 3754-3759.

19. Albandar JM, Muranga MB, Rams TE. Prevalence of aggressive periodontitis in school attendees in Uganda. $\mathrm{J}$ Clin Periodontol 2002; 29: 823-31.

20. Rajaram A, Kotrashetti VS, Somannavar $P D$, et al. Culture-based identification of pigmented Porphyromonas and Prevotella species in primary endodontic infections. $J$ Dent Res Dent Clin Dent Prospects 2016; 10: 136-141.

21. Mysak J, Podzimek S, Sommerova P, et al. Porphyromonas gingivalis: Major Periodontopathic Pathogen Overview. J Immunol Res 2014; 2014: 476068.

22. Borsanelli AC, Gaetti-Jardim E, Schweitzer $\mathrm{CM}$, et al. Black-pigmented anaerobic bacteria associated with ovine periodontitis. Vet Microbiol 2017; 203: 271274.

23. Susanto A, Carolina $D$, Amaliya $A$, et al. Periodontal health status and treatment needs of the community in Indonesia: A cross sectional study. J Int Oral Healty 2020; 12: 114-119.

24. Kadam NS, Patil R, Gurav AN, et al. Oral Hygiene Status, Periodontal Status, and Periodontal Treatment Needs among Institutionalized Intellectually Disabled Subjects in Kolhapur District, Maharashtra, India, Journal of Oral Diseases 2014, 1-11 